\title{
INFLUENCE OF OXYGEN IN INFLATION GAS DURING LUNG ISCHEMIA ON ISCHEMIA-REPERFUSION INJURY
}

Atsushi Watanabe, MD

Nobuyoshi Kawaharada, MD

Katsuyuki Kusajima, MD

Sakuzo Komatsu, MD

Tomio Abe, MD

Hiroki Takahashi, MD
Objectives: Previous studies have reported that hyperinflation during lung ischemia improves pulmonary function after reperfusion. However, it has not been clarified whether hyperinflation itself or oxygen in inflation gas causes good pulmonary function. The aim of this study is to evaluate the effect of oxygen in pulmonary inflation gas during lung ischemia on ischemia-reperfusion injury. Methods: Twenty-one mongrel dogs were randomly divided into three groups: the lung during a 90-minute period of warm ischemia was inflated to $30 \mathrm{~cm} \mathrm{H}_{2} \mathrm{O}$ with $100 \%$ oxygen in group $\mathrm{A}$ and $100 \%$ nitrogen in group B; it was not inflated in group C. Pulmonary function and hemodynamics were measured before ischemia and 1, 2, and 3 hours after reperfusion. Total protein and phosphorus of phospholipid in bronchoalveolar lavage fluid were measured 210 minutes after reperfusion. Adenine nucleotide levels in lung tissue were estimated 210 minutes after reperfusion. Results: No significant differences in pulmonary function and hemodynamics were noted between group $A$ and group $B$, but these two groups had significantly better pulmonary function and hemodynamics than group $\mathrm{C}$. No significant differences were detected in the concentrations of total protein and phosphorus of phospholipids in bronchoalveolar lavage fluid and in adenine nucleotide levels of lung tissue after reperfusion among the three groups. Conclusions: The results indicate that pulmonary inflation during warm ischemia improves pulmonary function and hemodynamics after reperfusion in this model. The effect is caused by inflation itself and is not due to oxygen as a metabolic substrate during warm ischemia. (J Thorac Cardiovasc Surg 1997;114:332-8) n lung transplantation, the transplanted donor lung sometimes shows transient depression of pulmonary function without rejection. This is called the reimplantation response and is caused by operative manipulations (e.g., transection of the bronchial arteries and lymph ducts or denervation of the vagus nerve) and ischemia-reperfusion injury. Ischemia and reperfusion are unavoidable processes in lung transplantation. Many studies ${ }^{1,2}$ have been con-

From the Second Department of Surgery and Third Department of Medicine, Sapporo Medical University School of Medicine, Sapporo, Japan.

Received for publication August 23, 1996; revisions requested Dec. 23, 1996; revisions received April 22, 1997; accepted for publication April 22, 1997.

Address for reprints: Atsushi Watanabe, MD, The Second Department of Surgery, Sapporo Medical University School of Medicine and Hospital, South 1, West 16, Chuo-ku, Sapporo 060, Japan.

Copyright (C) 1997 by Mosby-Year Book, Inc.

$0022-5223 / 97 \$ 5.00+0 \quad \mathbf{1 2 / 1 / 8 2 7 6 0}$ ducted on ways to decrease the ischemia-reperfusion injury in lung transplantation. Previous stud$\operatorname{ies}^{3,4}$ have reported that hyperinflation during ischemia without ventilation improves pulmonary function after reperfusion. However, it has not been clarified whether hyperinflation itself or oxygen in inflation gas causes good pulmonary function. Therefore this study was designed to clarify the effect of hyperinflation and oxygen in pulmonary inflation gas during warm ischemia on pulmonary function after reperfusion.

\section{Materials and methods}

Twenty-one mongrel dogs weighing 10 to $15 \mathrm{~kg}$ were divided into three groups: the lung during a 90-minute period of warm ischemia was inflated to $30 \mathrm{~cm} \mathrm{H}_{2} \mathrm{O}$ with $100 \%$ oxygen in group A $(n=7), 100 \%$ nitrogen in group $\mathrm{B}(n=7)$, and was not inflated in group $\mathrm{C}(n=7)$. The dogs were anesthetized with thiopental sodium $(20 \mathrm{mg} / \mathrm{kg})$ and intubated. Anesthesia was maintained with thiopental sodium ( $20 \mathrm{mg} / \mathrm{kg}$ per hour).

The dogs were placed in the spine position and their 
lungs were ventilated during the experiment with $100 \%$ oxygen at a rate of 12 to 20 times per minute, tidal volume of $20 \mathrm{ml} / \mathrm{kg}$, and positive end-expiratory pressure of $5 \mathrm{~cm}$ $\mathrm{H}_{2}$ O. A Swan-Ganz catheter (Baxter Edwards Division, Irvine, Calif.) was advanced to the pulmonary artery trunk through the jugular vein. A systemic arterial pressure line ( $7 \mathrm{~F}$ introducer) was positioned in the femoral artery and an extravascular lung water (EVLW) catheter (Surgitherm balloonless catheter, Electron Catheter Co., Rahway, N.J.) was positioned in the abdominal aorta through the introducer. An electrocardiogram, systemic and pulmonary artery pressure, right atrial pressure, and airway pressure were continuously monitored. Median sternotomy and left-sided pericardiectomy were performed. After complete hilar stripping, both of the main pulmonary arteries, the left pulmonary veins, and both of the main bronchi were dissected out and tape ligatures were passed around them. A left atrial pressure line was placed in the left atrium through the left atrial appendage. Heparin $(100 \mathrm{IU} / \mathrm{kg})$ was administered intravenously. After a 5minute occlusion of the right main pulmonary artery and main bronchus, baseline functional data of the left single lung, which was ventilated and perfused, were obtained from all the dogs. These included systemic artery, pulmonary artery, right atrial, left atrial, and airway pressures. Arterial blood gases were analyzed with an ABL-30 acid base analyzer (Radiometer A/S, Copenhagen, Denmark). Cardiac output was determined in triplicate by means of the thermodilution method. Pulmonary arterial resistance was calculated by the standard formula. EVLW volume was determined on the basis of a thermal-sodium double indicator-dilution method with a $3 \%$ cold sodium chloride solution ( 1 to $3 \mathrm{ml}$ ), which was injected into the right atrium (ETV 1100, Nihon Kohden Co., Tokyo, Japan). After baseline data assessment, the right main pulmonary artery and main bronchus were released, and the left main pulmonary artery was occluded. The left lung was inflated to $30 \mathrm{~cm} \mathrm{H}_{2} \mathrm{O}$ with $100 \%$ oxygen in group $\mathrm{A}, 100 \%$ nitrogen in group $B$, and not inflated in group $C$. Then the left main bronchus and the left pulmonary veins, together with a cuff of the left atrium, were occluded. The left lung was covered with a warm moist towel and its temperature was maintained within the range of $34^{\circ}$ to $37^{\circ} \mathrm{C}$. After a 90-minute period of warm ischemia of the left lung, the left main pulmonary artery, vein, and bronchus were released, and the left lung was reperfused and ventilated. The functional data 1, 2, and 3 hours after reperfusion were obtained in the same manner as the baseline functional data assessment. After all the functional data were obtained, 210 minutes after reperfusion, we transected the left intermediate bronchus and inserted an $8 \mathrm{~F}$ Foley balloon catheter (C. R. Bard, Inc., Billerica, Mass.) into the left lower bronchus. A $100 \mathrm{ml}$ dose of normal saline solution was gently injected directly into each left lower lobe after inflation of the left lower lobe had been confirmed by air injected through the catheter, and bronchoalveolar lavage (BAL) fluid was gently suctioned by means of a three-way stopcock at the end of the catheter after waiting a few minutes to allow lavage fluid to reach distal alveoli.

BAL fluid of the left lower lobe was obtained and pooled to yield a single specimen. The protein and phosphorus of organized phospholipid in BAL fluid were quantified as described later. The aspirated BAL fluid was centrifuged at a low speed ( $150 \mathrm{~g}$ for 10 minutes) to allow sedimentation of large particles. The resulting supernatant was extracted and stored at $-20^{\circ} \mathrm{C}$ or else was immediately used for analysis. The total nonsedimentable protein in BAL fluid was measured by the modified Lowry method. ${ }^{5}$ The organized phospholipid was extracted and purified by means of the method previously reported, ${ }^{6}$ and the phosphorus of organized phospholipid was measured as previously described.

A biopsy of left middle lobe was then carried out, and the biopsy samples were immediately frozen and stored in liquid nitrogen. Adenine nucleotides in each biopsy specimen were extracted with $0.5 \mathrm{~N}$ perchloric acid $\left(4^{\circ} \mathrm{C}\right)$ and neutralized. Levels of adenosine triphosphate (ATP), diphosphate (ADP), and monophosphate (AMP) were determined with high performance liquid chromatography $^{8}$ (HPLC system, Nihonbunko Co., Ltd., Tokyo, Japan) (Fig 1).

Statistics. The textbook Statistical Methods in Medical Research ${ }^{9}$ was our reference for study design and statistical methods. Statistical analyses were done with a Macintosh Power Mac 8500 computer (Apple Computer, Inc., Cupertino, Calif.) and StatView 4.0 statistical system (Abacus Concepts, Berkeley, Calif.). All values were expressed as mean \pm standard deviation of the mean. Independent sample comparisons were made for all experimental results by means of one-way factorial analysis of variance (ANOVA) and Fisher's Paired Least Significant Difference test as a post hoc test. A $p$ value less than 0.05 was considered to be statistically significant.

Animal care. All dogs received humane care in compliance with the "Principles of Laboratory Animal Care" formulated by the National Society for Medical Research and the "Guide for the Care and Use of Laboratory Animals" prepared by the National Academy of Sciences and published by the National Institutes of Health (NIH Publication No. 80-23, revised 1987).

\section{Results}

Blood gas analysis. Baseline arterial oxygen tension was similar among the three groups (602 \pm 19 $\mathrm{mm} \mathrm{Hg}$ in group $\mathrm{A}, 604 \pm 13 \mathrm{~mm} \mathrm{Hg}$ in group B, and $596 \pm 15 \mathrm{~mm} \mathrm{Hg}$ in group C). Arterial oxygen tension for 2 to 3 hours after reperfusion was significantly higher in group A and group B than in group $\mathrm{C}$, but no significant differences were noted between group A and group B (601 $\pm 40 \mathrm{~mm} \mathrm{Hg}$ in group A, $588 \pm 29 \mathrm{~mm} \mathrm{Hg}$ in group B, and $355 \pm$ $213 \mathrm{~mm} \mathrm{Hg}$ in group $\mathrm{C} 3$ hours after reperfusion; ANOVA: $p=0.0024$, A vs C: $p=0.001$, B vs C: $p=$ $0.0041)$. Baseline alveolar-arterial oxygen tension difference was similar among the three groups (69 \pm $16 \mathrm{~mm} \mathrm{Hg}$ in group $\mathrm{A}, 71 \pm 10 \mathrm{~mm} \mathrm{Hg}$ in group B, and $79 \pm 14 \mathrm{~mm} \mathrm{Hg}$ in group C). Alveolar-arterial oxygen tension difference 2 to 3 hours after reperfusion was significantly lower in group $A$ and group 


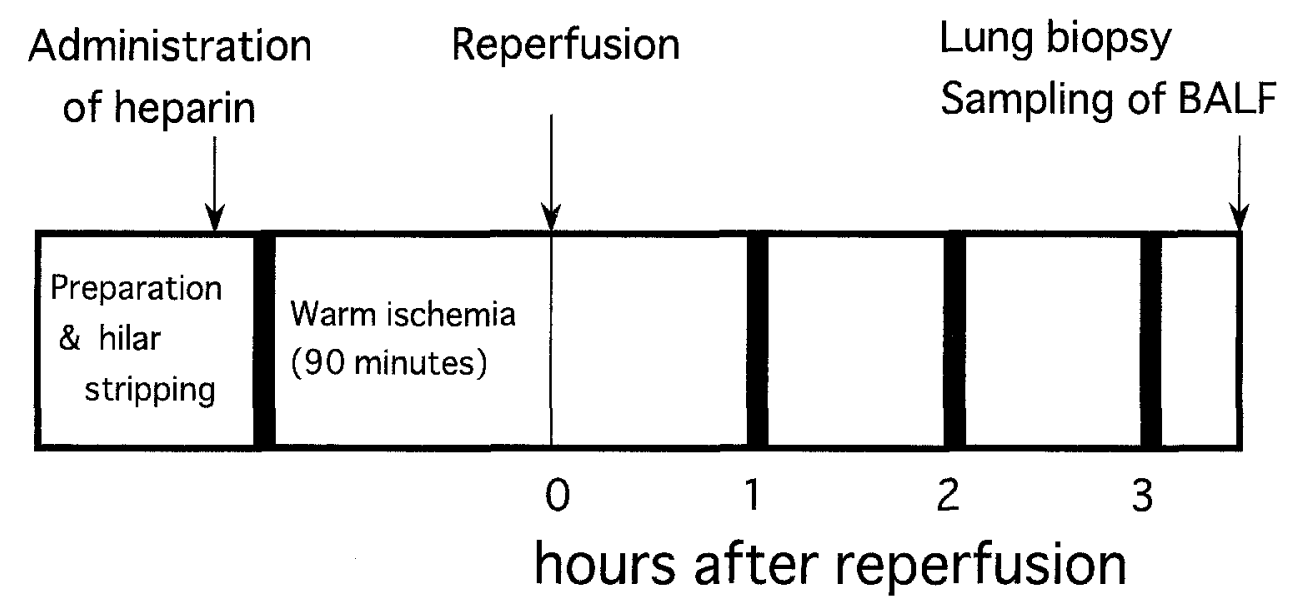

5-minute occlusion of right main pulmonary artery and main bronchus to measure blood gas, hemodynamics, air way pressure and extra vascular lung water volume

Fig 1. Experimental protocol. The left lung was inflated to $30 \mathrm{~cm} \mathrm{H}_{2} \mathrm{O}$ with $100 \%$ oxygen in group $\mathrm{A}$ and $100 \%$ nitrogen in group $\mathrm{B}$, but it was not inflated in group $\mathrm{C}$ during a 90 -minute period of warm ischemia. $B A L F$, Bronchoalveolar lavage fluid.

B than in group $\mathrm{C}$, but no significant differences were detected between group A and group B (69 \pm $40 \mathrm{~mm} \mathrm{Hg}$ in group A, $80 \pm 29 \mathrm{~mm} \mathrm{Hg}$ in group B, and $307 \pm 200 \mathrm{~mm} \mathrm{Hg}$ in group $\mathrm{C}$ at 3 hours after reperfusion; ANOVA: $P=0.0021$, A vs $\mathrm{C}: p=$ 0.0011 , B vs C: $p=0.0044$ ) (Table I).

Hemodynamics. Baseline cardiac output was similar among the three groups $(1.66 \pm 0.45 \mathrm{~L} / \mathrm{min}$ in group $\mathrm{A}, 1.54 \pm 0.30 \mathrm{~L} / \mathrm{min}$ in group $\mathrm{B}$, and $1.50 \pm$ $0.31 \mathrm{~L} / \mathrm{min}$ in group C). Cardiac output for 1 to 3 hours after reperfusion showed no significant differences among the three groups $(1.37 \pm 0.26 \mathrm{~L} / \mathrm{min}$ in group $\mathrm{A}, 1.13 \pm 0.58 \mathrm{~L} / \mathrm{min}$ in group $\mathrm{B}$, and $0.97 \pm$ $0.20 \mathrm{~L} / \mathrm{min}$ in group $\mathrm{C} 3$ hours after reperfusion; ANOVA: $p=0.1011$ ). Baseline pulmonary arterial resistance also was similar among the three groups $\left(1002 \pm 415 \mathrm{dyne} \cdot \mathrm{sec} \cdot \mathrm{cm}^{-5}\right.$ in group A, $999 \pm 501$ dyne $\cdot \mathrm{sec} \cdot \mathrm{cm}^{-5}$ in group $\mathrm{B}$, and $1062 \pm 295$ dyne $\cdot \mathrm{sec} \cdot \mathrm{cm}^{-5}$ in group C). Pulmonary arterial resistance was significantly higher 3 hours after reperfusion in group $\mathrm{C}$ compared with that in group $\mathrm{A}$ or group B (1074 \pm 505 dyne $\cdot \mathrm{sec} \cdot \mathrm{cm}^{-5}$ in group A, $1205 \pm 622$ dyne $\cdot \mathrm{sec} \cdot \mathrm{cm}^{-5}$ in group $\mathrm{B}$, and $1781 \pm$ 134 dyne $\cdot \mathrm{sec} \cdot \mathrm{cm}^{-5}$ in group C; ANOVA: $p=$ 0.0132 , A vs C: $p=0.0053$, B vs $\mathrm{C}: p=0.0283$ ) (Table I).

EVLW volume. Baseline EVLW volume was similar among the three groups $(5.63 \pm 0.89 \mathrm{ml} / \mathrm{kg}$ in group A, $5.48 \pm 0.99 \mathrm{ml} / \mathrm{kg}$ in group $\mathrm{B}$, and $5.41 \pm$ $1.87 \mathrm{ml} / \mathrm{kg}$ in group C). EVLW volume after reperfusion gradually increased in all three groups, and 3 hours after reperfusion it was significantly higher in group $\mathrm{C}$ than in group A or group B (7.91 \pm 2.08 $\mathrm{ml} / \mathrm{kg}$ in group $\mathrm{A}, 7.14 \pm 1.35 \mathrm{ml} / \mathrm{kg}$ in group $\mathrm{B}$, and $10.87 \pm 2.32 \mathrm{ml} / \mathrm{kg}$ in group C; ANOVA: $p=$ 0.0049 ; A vs $\mathrm{C}, p=0.0082$; $\mathrm{B}$ vs $\mathrm{C}, p=0.0027$ ) (Table I).

Peak airway pressure. Baseline peak airway pressure was similar among the three groups $(9 \pm 2 \mathrm{~cm}$ $\mathrm{H}_{2} \mathrm{O}$ in group $\mathrm{A}, 9 \pm 2 \mathrm{~cm} \mathrm{H}_{2} \mathrm{O}$ in group $\mathrm{B}$, and $11 \pm 4 \mathrm{~cm} \mathrm{H}_{2} \mathrm{O}$ in group $\mathrm{C}$ ). Peak airway pressure 3 hours after reperfusion was significantly higher in group $C$ than in either group $A$ or group $C(16 \pm 5$ $\mathrm{cm} \mathrm{H}_{2} \mathrm{O}$ in group $\mathrm{A}, 13 \pm 2 \mathrm{~cm} \mathrm{H}_{2} \mathrm{O}$ in group $\mathrm{B}$, and $22 \pm 8 \mathrm{~cm} \mathrm{H} \mathrm{H}_{2} \mathrm{O}$ in group C; ANOVA: $p=0.0217$; $\mathrm{A}$ vs $\mathrm{C}, p=0.049$; $\mathrm{B}$ vs $\mathrm{C}, p=0.0079$ ) (see Table I).

Total protein and phosphorus of phospholipid in BAL fluid. Total protein concentration in BAL fluid 3 hours after reperfusion was higher in group $C$ than in either group A or group B, but the differences did not reach statistical significance $(181.8 \pm 73.6 \mathrm{mg} / \mathrm{ml}$ in group $\mathrm{A}, 158.1 \pm 78.7 \mathrm{mg} / \mathrm{ml}$ in group $\mathrm{B}$, and $262.5 \pm 150.3 \mathrm{mg} / \mathrm{ml}$ in group $\mathrm{C}$ ). Phosphorus concentration of phospholipid in BAL fluid 3 hours after reperfusion was similar among the three groups $(0.25 \pm 0.11 \mu \mathrm{mol} / \mathrm{ml}$ in group A, $0.30 \pm 0.12$ 
Table I. Assessment of pulmonary function

\begin{tabular}{|c|c|c|c|c|c|}
\hline Parameter & Group & Baseline & $R 1$ & $R 2$ & $R 3$ \\
\hline \multirow[t]{3}{*}{$\mathrm{PaO}_{2}(\mathrm{~mm} \mathrm{Hg})$} & A & $602 \pm 19$ & $593 \pm 33$ & $595 \pm 63^{*}$ & $601 \pm 40^{*}$ \\
\hline & $\mathrm{B}$ & $604 \pm 13$ & $594 \pm 5$ & $586 \pm 9$ & $588 \pm 29$ \\
\hline & $\mathrm{C}$ & $596 \pm 15$ & $548 \pm 75$ & $422 \pm 144 \dagger \ddagger$ & $355 \pm 213+t$ \\
\hline \multirow[t]{3}{*}{$\mathrm{P}(\mathrm{A}-\mathrm{a}) \mathrm{O}_{2}(\mathrm{~mm} \mathrm{Hg})$} & $\mathrm{A}$ & $69 \pm 16$ & $79 \pm 27$ & $78 \pm 59^{*}$ & $69 \pm 40^{*}$ \\
\hline & $\mathrm{B}$ & $71 \pm 10$ & $86 \pm 7$ & $92 \pm 9$ & $90 \pm 29$ \\
\hline & $\mathrm{C}$ & $79 \pm 14$ & $123 \pm 68$ & $246 \pm 138+t$ & $307 \pm 200+t$ \\
\hline \multirow[t]{3}{*}{$\mathrm{CO}(\mathrm{L} / \mathrm{min})$} & A & $1.66 \pm 0.45$ & $1.34 \pm 0.49$ & $1.38 \pm 0.46$ & $1.37 \pm 0.26$ \\
\hline & $\mathrm{B}$ & $1.54 \pm 0.3$ & $0.99 \pm 0.41$ & $1.14 \pm 0.51$ & $1.13 \pm 0.58$ \\
\hline & $\mathrm{C}$ & $1.5 \pm 0.31$ & $1.03 \pm 0.12$ & $1.19 \pm 0.49$ & $0.97 \pm 0.2$ \\
\hline \multirow[t]{3}{*}{$\operatorname{PAR}\left(\right.$ dyne $\cdot \mathrm{sec} \cdot \mathrm{cm}^{-5}$ ) } & A & $1004 \pm 443$ & $906 \pm 536$ & $1010 \pm 445$ & $1074 \pm 505^{*}$ \\
\hline & $\mathrm{B}$ & $996 \pm 448$ & $1216 \pm 495$ & $1138 \pm 574$ & $1205 \pm 622$ \\
\hline & $\mathrm{C}$ & $1062 \pm 295$ & $1195 \pm 479$ & $1465 \pm 318$ & $1781 \pm 134 \dagger$ \\
\hline \multirow[t]{3}{*}{ EVLW $(\mathrm{ml} / \mathrm{kg})$} & A & $5.63 \pm 0.89$ & $7.65 \pm 2.33$ & $8.17 \pm 2.36$ & $7.91 \pm 2.08^{*}$ \\
\hline & B & $5.48 \pm 0.99$ & $5.93 \pm 1.5$ & $6.55 \pm 0.82$ & $7.14 \pm 1.35$ \\
\hline & $\mathrm{C}$ & $5.41 \pm 1.87$ & $8.28 \pm 4.18$ & $8.89 \pm 2.38$ & $10.87 \pm 2.32 \dagger \dagger$ \\
\hline \multirow[t]{3}{*}{ Peak PAW $\left(\mathrm{cm} \mathrm{H}_{2} \mathrm{O}\right)$} & A & $9 \pm 2$ & $13 \pm 4$ & $17 \pm 6$ & $16 \pm 5$ \\
\hline & $\mathrm{B}$ & $9 \pm 2$ & $11 \pm 2$ & $12 \pm 2$ & $13 \pm 2$ \\
\hline & $\mathrm{C}$ & $11 \pm 4$ & $16 \pm 6$ & $20 \pm 9$ & $22 \pm 8 \uparrow t$ \\
\hline
\end{tabular}

Data are shown as mean \pm standard deviation. $R 1, R 2, R 3,1,2,3$, hours after reperfusion, respectively; $P a O_{2}$, arterial oxygen tension; $P(A-a) O_{2}$, alveolar-arterial difference of oxygen tension; $C O$, cardiac output $(\mathrm{L} / \mathrm{min}) ; P A R$, pulmonary arterial resistance; $E V L W$, extravascular lung water volume; $P A W$, airway pressure.

${ }^{*} P<0.05$ by ANOVA.

$\dagger p<0.05$ versus group A.

$\ddagger p<0.05$ versus group $\mathbf{B}$.

$\mu \mathrm{mol} / \mathrm{ml}$ in group $\mathrm{B}$, and $0.32 \pm 0.14 \mu \mathrm{mol} / \mathrm{ml}$ in group C) (Table II).

Adenine nucleotide levels and energy charge in lung biopsy sample. The levels of cellular AMP, $\mathrm{ADP}, \mathrm{ATP}$, and energy charge 3 hours after reperfusion showed no significant differences among the three groups (ATP and energy charge: $0.88 \pm 0.85$ $\mu \mathrm{mol} / \mathrm{gm}$ tissue wet weight and $0.12 \pm 0.07$ in group A, $0.76 \pm 0.62 \mu \mathrm{mol} / \mathrm{gm}$ tissue wet weight and $0.11 \pm 0.07$ in group $\mathrm{B}$, and $0.90 \pm 0.82 \mu \mathrm{mol} / \mathrm{gm}$ tissue wet weight and $0.13 \pm 0.08$ in group $\mathrm{C}$, respectively) (Table III).

\section{Discussion}

Inflation of the lung has been known to affect pulmonary vascular tone. ${ }^{10}$ Hyperinflation ${ }^{11,12}$ and intracellular alkalosis ${ }^{13}$ have also been known to promote the release of pulmonary surfactant from type II pneumocytes. Owing to these reports, the donor lung was able to be clinically preserved in the inflated state without ventilation during lung transplantation. Puskas and colleagues ${ }^{14}$ reported that in the canine lung transplantation model, hyperinflation of the donor lung during hypothermic preservation for $\mathbf{3 0}$ hours reduced ischemia-reperfusion injury, and the inflated lung maintained better posttransplantation pulmonary function than the noninflated or semiinflated lung. They speculated that the beneficial effect of donor hyperinflation may be exerted through a more efficacious pulmonary artery flush as a result of pulmonary vasodilation and avoidance of atelectasis, by an increased surfactant release and conservation in donor lungs, by prevention of damaging alveolar collapse during hypothermic storage, or by a combination of these factors. In addition, hyperinflation with $100 \%$ oxygen may be beneficial by providing oxygen as a metabolic substrate and by limiting the localized hypoxia associated with atelectasis. In another study, ${ }^{15}$ canine pulmonary lobes perfused ex vivo with hypothermic Euro-Collins solution showed a higher pulmonary vascular compliance and significantly lower vascular closure pressure when statically inflated with oxygen than when atelectatic. It is thought that the effect might contribute to squeezing blood from the pulmonary vasculature and avoiding hypoxic pulmonary vasoconstriction. On the other hand, Detterveck and coworkers ${ }^{16}$ reported that 8 of 12 recipients survived the 12-hour posttransplantation assessment in lung transplantation using canine donor lungs flushed with Euro-Collins solution and then hyperinflated to 23 to $30 \mathrm{~cm} \mathrm{H}_{2} \mathrm{O}$ pressure with $100 \%$ nitrogen gas before storage at $4^{\circ} \mathrm{C}$ for 24 hours. Their data suggest that static hyperinflation, even with nitrogen gas, is highly beneficial to lung preservation. Although these reports showed that 
Table II. Total protein and phosphorus of phospholipid in BAL lavage fluid 210 minutes after reperfusion

\begin{tabular}{lcccc}
\hline & Group $A$ & Group $B$ & Group $C$ & $p$ Value \\
\hline Total protein $(\mathrm{mg} / \mathrm{ml})$ & $181.8 \pm 73.6$ & $158.1 \pm 78.7$ & $262.5 \pm 150.3$ & 0.206 \\
Phosphorous $(\mu \mathrm{mol} / \mathrm{ml})$ & $0.25 \pm 0.11$ & $0.30 \pm 0.12$ & $0.32 \pm 0.14$ & 0.635 \\
\hline
\end{tabular}

Data are shown as mean \pm standard deviation.

Table III. Adenine nucleotide levels and energy charge in lung tissue 210 minutes after reperfusion

\begin{tabular}{lrrrr}
\hline & \multicolumn{1}{c}{ Group A } & \multicolumn{1}{c}{ Group B } & \multicolumn{1}{c}{ Group C } & $p$ Value \\
\hline AMP $(\mu \mathrm{mol} / \mathrm{gm}$ tissue wet weight) & $11.35 \pm 1.87$ & $11.80 \pm 2.44$ & $11.13 \pm 4.91$ & 0.9364 \\
ADP $(\mu \mathrm{mol} / \mathrm{gm}$ tissue wet weight) & $1.77 \pm 0.99$ & $1.71 \pm 0.91$ & $1.81 \pm 0.99$ & 0.9789 \\
ATP $(\mu \mathrm{mol} / \mathrm{gm}$ tissue wet weight $)$ & $0.88 \pm 0.85$ & $0.76 \pm 0.62$ & $0.90 \pm 0.82$ & 0.9438 \\
EC & $0.12 \pm 0.07$ & $0.11 \pm 0.07$ & $0.13 \pm 0.08$ & 0.9106 \\
\hline
\end{tabular}

Data are shown as mean \pm standard deviation. $A M P$, Adenosine monophosphate; $A D P$, adenosine diphosphate; $A T P$, adenosine triphosphate; $E C$, energy charge.

hyperinflation of the donor lung during preservation improved posttransplantation pulmonary function, they did not report whether oxygen in the inflation gas has an effect on posttransplantation pulmonary function. On the other hand, Koyama and cowork$\mathrm{ers}^{17}$ described superior preservation of lungs ventilated with $100 \%$ nitrogen compared with those ventilated with room air or $100 \%$ oxygen. The aim of the present study was to clarify the effect of hyperinflation and oxygen in the hyperinflation gas during lung preservation on pulmonary function after ischemia and reperfusion. For the experiments, we used 90 minutes of warm ischemia and reperfusion in a canine model. This canine model was considered to be adequate for determining the effect, because the model is simple and not affected by the lung transplantation procedure and rejection, and it is possible to create ischemia-reperfusion injury early. Furthermore, Date and associates ${ }^{18}$ demonstrated that during the first 4 hours of preservation, the metabolic rates of rabbit lungs that were inflated with room air at $1^{\circ}, 10^{\circ}$, and $22^{\circ} \mathrm{C}$ were $4 \%, 10 \%$, and $28 \%$, respectively, of the metabolic rate (about $0.58 \mathrm{ml} / \mathrm{gm}$ wet weight per hour) of the perfused dog lung at $37.5^{\circ} \mathrm{C}$, as observed by Weber and Visscher. ${ }^{19}$ In other words, oxygen consumption during ischemia is higher in warm ischemia than in cold ischemia. Therefore we considered that the effect of oxygen in inflation gas during ischemia could be observed better in warm ischemia than in cold ischemia. Although it is generally considered that a 5-minute period of occlusion of the contralateral pulmonary artery and main bronchus may not be sufficient to obtain reliable blood gas and hemodynamic results from an ischemic-reperfused lung, we found no significant differences or significant correlations in blood gas and hemodynamic results among 5, 10, 15, and 20 minutes of occlusion of them in this model. In this study, we used arterial oxygen tension, alveolar-arterial oxygen tension difference, cardiac output, pulmonary arterial resistance, and peak airway pressure as parameters of pulmonary function. We used EVLW volume as a parameter of pulmonary edema, total protein in BAL fluid as an indicator of capillary-alveolar cell membrane permeability, phosphorus of phospholipid in BAL fluid as an indirect indicator of pulmonary surfactant, and adenine nucleotides as a parameter of the energy state. EVLW volume was measured by means of the thermal (dilution indicator) sodium (nondilution indicator) double indicator dilution method. This method is simple and EVLW volume could be repeatedly measured. Ishibe, Suemasu, and Sagawa ${ }^{20}$ reported that in their experimental study, EVLW volume measured by means of this method was almost equal to that directly measured as previously described. ${ }^{21}$

Blood gas analysis and pulmonary arterial resistance were significantly better in the hyperinflation group than the noninflation group, but no significant differences were detected in blood gas analysis and pulmonary arterial resistance between the oxygen hyperinflation group and the nitrogen hyperinflation group. These results indicate that hyperinflation itself during lung ischemia without ventilation affects pulmonary function after reperfusion, but oxygen in hyperinflation gas has no effect.

EVLW volume was significantly higher in the noninflation group than in the hyperinflation group, but showed no significant differences between the oxygen hyperinflation group and the nitrogen hyperinflation group. The changes of EVLW volume 
follow Staring's law. ${ }^{22}$ Mechanisms of pulmonary edema are alternations in the permeability of pulmonary vascular membranes, increases in pulmonary hydrostatic pressure, and failure of normal clearance of extravascular fluid by the pulmonary lymphatic system or by decreases in colloid osmotic pressure. In the present study, it was thought that there were no differences in the failure of normal clearance of extravascular fluid among the three groups, because the same intravenous infusion and operative procedures were performed in all groups. Thus the differences in EVLW volume between the hyperinflation group and the noninflation group were thought to result from the mechanisms of alterations in the permeability and increases in pulmonary hydrostatic pressure.

No significant differences were detected in the protein concentration and the concentration of phosphorus of phospholipid in BAL fluid among the three groups. It was thought, however, that the protein concentration and the concentration of phosphorus of phospholipid in BAL fluid might not play roles as an indicator of capillary-alveolar cell membrane permeability and as an indirect indicator of pulmonary surfactant, respectively; bleeding into the alveoli was detected in all three groups, and bleeding may distort the true value of the protein permeating through the capillary-alveolar membrane into the alveoli and the phosphorus of pulmonary surfactant existing in the alveoli. It is unlikely that these indirect parameters were sufficient to estimate the true values. It is necessary to use a gamma counter to measure the value of radiolabeled protein permeating through the capillaryalveolar membrane after an intravenous injection of radiolabeled protein ${ }^{23,24}$; it is also necessary to use the value of dipamytoile phosphatidyl choline ${ }^{25}$ or phosphatidyl glycerol, which are specific phospholipids of pulmonary surfactant, to estimate the true values of the protein permeating through capillaryalveolar membrane and pulmonary surfactant. Furthermore, Veldhuizen and associates ${ }^{26}$ reported that after an ischemic time of 12 hours, impaired gas exchange was observed in the left transplanted lung as well as the native right lung during the 6 hours of reperfusion in an experimental lung transplantation model, and the ratio of small to large surfactant aggregates in the lung lavage was increased. The ratio has recently been recognized as a sensitive indicator of the quality of lung preservation.

Adenine nucleotide levels and energy charge in lung biopsy samples showed no significant differ- ences among the three groups. The ATP level was 0.76 to $0.90 \mu \mathrm{mol} / \mathrm{gm}$ tissue wet weight and the energy charge was 0.11 to 0.13 . Previous studies ${ }^{27,28}$ reported that the ATP level was about to 1.0 $\mu \mathrm{mol} / \mathrm{gm}$ tissue wet weight and the energy charge was about 0.85 in lung tissue under a balanced state of energy metabolism. The present ATP level and energy charge demonstrate that a 90 -minute period of warm ischemia of the lung causes deterioration of the energy state after reperfusion.

The results of the present study lead to the following conclusions: (1) Hyperinflation of the lung during a 90-minute period of warm ischemia reduces the pulmonary injury after reperfusion compared with noninflation. (2) Hyperinflation reduces the increase of EVLW volume after reperfusion. (3) No effect of the presence of oxygen in hyperinflation gas on the pulmonary function after ischemia-reperfusion was detected in the model. It is unclear whether the effect is due to facilitating the release of the pulmonary surfactant, although it is thought that the effect is due to the prevention of atelectasis, maintaining the pulmonary vascular tone, and squeezing blood from the pulmonary vasculature by hyperinflation itself.

Our findings contradict those in a recent study by Weder and coworkers, ${ }^{29}$ who described superior preservation of a lung inflated with $100 \%$ oxygen compared with that inflated with room air or $100 \%$ nitrogen during 24 hours of cold ischemia $\left(10^{\circ} \mathrm{C}\right)$ in a rabbit model. Furthermore, Date and associates ${ }^{18}$ demonstrated that lung cells are able to maintain aerobic metabolism with the oxygen in the alveoli during 24 hours of cold preservation in an excised rabbit lung model flushed with low-potassium dextran electrolyte solution. They also showed that the maintenance of aerobic metabolism may be essential to maintain the viability of preserved lung tissue. Furthermore, they reported that preservation was better at $10^{\circ} \mathrm{C}$ than at $2^{\circ} \mathrm{C}$. We hypothesize that the difference in results is caused by the difference of the lung temperature during ischemia, inflation pressure, and the existence of intravascular oxygenated blood in the ischemic lung. The oxygen may be supplied to pulmonary cells during ischemia by intravascular oxygenated blood in the ischemic lung if intravascular oxygenated blood in the lung was not flushed and has remained. Otherwise, the effect of hyperinflation of the lung during ischemia on lung function may be much higher than that of oxygen in inflation gas. Further investigation is needed to clarify this hypothesis. 
No effect of the presence of oxygen in hyperinflation gas on pulmonary function after ischemiareperfusion could be detected in this model.

\section{REFERENCES}

1. Kirk AJ, Colquhoun IW, Dark JH. Lung preservation: a review of current practice and future directions. Ann Thorac Surg 1993;56:990-1000.

2. Novic RJ, Gehman KE, Ali IS, Lee J. Lung preservation: the importance of endothelial and alveolar type II cell integrity. Ann Thorac Surg 1996;62:302-14.

3. Veith FJ, Sinha SBP, Graves JS, Boley SJ, Dougherty JC. Ischemic tolerance of the lung: the effect of ventilation and inflation. J Thorac Cardiovasc Surg 1971;61:804-10.

4. Stevens GH, Sanchez MM, Cappell GL. Enhancement of lung preservation by prevention of lung collapse. J Surg Res 1973;14:400-5.

5. Peterson GH. A simplification of the protein assay method of Lowry et al., which is more generally applicable. Anal Biochem 1977;83:346-56.

6. Bligh EG, Dyer WJ. A rapid method of total lipid extraction and purification. Can J Biochem Physiol 1959;37:911-7.

7. Bartlett GR. Phosphorus assay in column chromatography. J Biol Chem 1959;234:466-8.

8. Endo I, Utsugi M, Suzuki T, Karaki H. Method for simultaneous determination of creatine phosphate and adenine nucleotides in intestinal smooth muscle of guinea-pig taenia caeci using high performance liquid chromatography. J Smooth Muscle Res 1988;24:127-30.

9. Armitage P, Berry G. Statistical methods in medical research. 3rd ed. Oxford: Blackwell Science, 1994.

10. Burton AC, Patel DJ. Effect on pulmonary vascular resistance of inflation of the rabbit lungs. J Appl Physiol 1958;12: 239-46.

11. Faridy EE. Effect of distension on release of surfactant in excised dogs' lungs. Respir Physiol 1976;27:99-114.

12. Nicholas TE, Barr HA. Control of release of surfactant phospholipids in the isolated perfused rat lung. J Appl Physiol 1981;51:90-8.

13. Chander A, Fisher AB. Regulation of lung surfactant secretion. Am J Physiol 1990;258:241-53.

14. Puskas JD, Hirai T, Christie N, Mayer E, Slutsky AS, Patterson A. Reliable thirty-hour lung preservation by donor lung hyperinflation. J Thorac Cardiovasc Surg 1992;104:107583.

15. Unruh H, Happensack M, Oppenheimer L, Vascular properties of canine lung perfused with Euro-Collins solution and prostacyclin. Ann Thorac Surg 1990;49:292-8.

16. Detterbeck FC, Keagy BA, Paull DE, Wilcox BR. Oxygen free radical scavengers decrease reperfusion injury in lung transplantation. Ann Thorac Surg 1990;50:204-10.

17. Koyama I, Toung TJK, Rogers MC, Gurtner GH, Traystman RJ. $\mathrm{O}_{2}$ radicals mediate reperfusion injury in ischemic $\mathrm{O}_{2}$ ventilated canine pulmonary lobe. J Appl Physiol 1987;63: 111-5.

18. Date H, Matsumura A, Manchester JK, Cooper JM, Lowry $\mathrm{OH}$, Cooper JD. Changes in alveolar oxygen and carbon dioxide concentration and oxygen consumption during lung preservation. J Thorac Cardiovasc Surg 1993;105:492-501.

19. Weber KC, Visscher MB. Metabolism of the isolated canine lung. Am J Physiol 1969;217:1044-52.

20. Ishibe Y, Suemasu K, Sagawa Y. Experimental study of extra vascular lung water volume using thermal-sodium double indicator technique. Masui 1986;35:373-8.

21. Pearce ML, Beazell JW. The measurement of pulmonary parenchymal volume by thermal indicator dilution (abstract). Clin Res 1966;14:182.

22. Staring EH. On the absorption of fluids from the connective tissue spaces. J Physiol 1896;19:312-26.

23. Parker JC, Parker RE, Granger DN, Taylor AE. Vascular permeability and transvascular fluid and protein transport in dog lung. Circ Res 1981;48:548-61.

24. Dauber IM, Pluss WT, VanGrondelle A, Trow RS, Weil JV. Specificity and sensitivity of noninvasive measurement of pulmonary vascular protein leak. J Appl Physiol 1985;59:56474.

25. Klepetko W, Lohninger A, Wisser W, Mueller MR, KhünlBrady G, Windisch A, Eckersberger F, Wolner E. Pulmonary surfactant in bronchoalveolar lavage after canine lung transplantation: effect of 1-carnitine application. J Thorac Cardiovasc Surg 1990;99:1048-58.

26. Veldhuizen RA, Lee J, Sandler D, Hull W. Alterations in pulmonary surfactant composition and activity after experimental lung transplantation. Am Rev Respir Dis 1993;148: 208-15.

27. Date H, Lima O, Matsumura A, Tsuji H, d'Avignon DA, Cooper JD. In a canine model, lung preservation at $10^{\circ} \mathrm{C}$ is superior to that at $4^{\circ} \mathrm{C}$ : a comparison of two preservation temperatures on lung function and on adenosine triphosphate level measured by phosphorus 31-nuclear magnetic resonance. J Thorac Cardiovasc Surg 1992;103:773-80.

28. Hall TS, Buescher PC, Borkon AM, Reitz BA, Michael JR, Baumgartner WA. 31P Nuclear magnetic resonance determination of changes in energy state in lung preservation. Circulation 1988;78(Suppl):III95-8.

29. Weder W, Harper B, Shimokawa S, Miyoshi S, Date H, Schreinemakers $\mathrm{H}$, et al. Influence of intraalveolar oxygen concentration on lung preservation in rabbit model. $\mathrm{J}$ Thorac Cardiovasc Surg 1991;101:1037-43. 